\title{
CATEGORIZATION OF ASSESSMENT SYSTEM OF MANAGERIAL COMPETENCIES IN POLISH ENTERPRISES - RESEARCH RESULTS
}

\author{
Małgorzata Tyrańska \\ Cracow University of Economics, Faculty of Management, \\ Cracow, Poland \\ e-mail: malgorzata.tyranska@uek.krakow.pl
}

\begin{abstract}
Purpose: Main purpose of the article is to present the assumptions, procedures and results of the application of the categorization method, which identifies the degree of fulfilment of the distinguished functions by the assessment systems of competencies of management staff used in the practice of the surveyed enterprises. For the purposes of the article the author assumes that the assessment system of competencies of management staff is creating the complementary arrangement of formalization, diagnostic and motivational functions assessing the level of managerial competencies and inspiring the management staff to accept ethical and efficiency attitudes.

Methodology/approach: The research had a regional coverage. The research covered 197 enterprises located in south-eastern Poland, operating in various industries in the Lesser Poland, Silesian and Podkarpackie voivodeships. In order to collect data, an interview method was used. It was carried out with the management staff or the managers of personal departments in the surveyed enterprises. The article presents the essence of the distinguished functions as well as assumptions, procedures and results of implementation of the categorization method which is used to identify the utility of the assessment system of competencies of management staff by determining the degree of fulfilment of the functions by systems applicable in the practice of the surveyed enterprises.
\end{abstract}

Findings: Results of the research confirmed the hypothesis that the assessment systems of Polish enterprises in incomplete range allow for an overall assessment of managerial competencies.

Implications: Managerial competencies, as the dynamic structure, are changing, developing or cancelling out. Therefore, these competencies should be assessed as a part of the assessment system in order to identify competency gap, which appearing can prevent execution of current tasks of the enterprise, hinder its development and constitute the barrier strengthening competitive position.

Originality/value of the paper: Identifying important issues for the assessment systems of Polish enterprises help in formulating the directions of their improvement.

Keywords: assessment system of managerial competencies, functions of the assessment system of managerial competencies, the procedure of categorization of assessment systems of managerial competencies

Paper type: Research paper 
CATEGORIZATION OF ASSESSMENT SYSTEM

Małgorzata Tyrańska

\section{Introduction}

Managerial competencies are understood as a set of features of a manager, including his: personality, knowledge, skills, attitudes, experience and responsibility [1]. They remain in the cause - effect relationship with the manager behaviour that determine the effective (Nesterak, 2010; Semeijn et al., 2014), efficient and ethical management (Dalton, 1997; Mansfield, 1999; Gholipur and Mahmoodi, 2012). It should be noted that managerial competencies, as a dynamic structure, are changing. The direction of these changes does not always have to be positive, indicating their development. They may also become outdated. The incompetence of managers, resulting from ignorance, lack of experience in business management, leads to ineptitude of their actions. It may result in the failure to make the right decision in due time, the tendency to implement preservative actions, the choice of safer solutions, and the avoidance of difficulties. Therefore, the competencies of management staff should be assessed in order to identify a competency gap that may prevent the enterprise from carrying out its current tasks, hinder its development, and be a barrier to strengthening its competitive position.

Thus, the operationalization of the assessment system of competencies of management staff requires the use of a well-thought-out procedure, which is implemented within the framework of the assessment system of the competencies of management staff (ASCMS). The ASCMS is a complementary system of formalization, diagnostic and motivational functions that value the level of managerial competencies. The formalization function of the ASCMS aims to stabilize the principles of personal policy in an organization by creating and ensuring compliance with procedural requirements of the assessment of managerial competencies. The diagnostic function leads to the identification of the competency gap in managerial positions. While, the motivational function is focused on shaping the ethical and pro-efficiency attitudes and behaviours of managers.

The purpose of the article is to present the assumptions, procedures and results of the application of the categorization method, which identifies the degree of fulfilment of the distinguished functions by the assessment systems of competencies of management staff used in the practice of the surveyed enterprises. The goal of the research was based on the hypothesis that the assessment systems of Polish enterprises in incomplete range allow for an overall assessment of managerial competencies.

\section{Assumptions of the procedure for categorizing the assessment systems of competencies of management staff}

The results of previous research prejudge the need to carry out research that identifies the level of functionality of the assessment systems of competencies of management staff in business practice. The results of research on assessment 
systems indicate the importance of this area in human resource management (Pocztowski, 2007; Urbaniak and Bohdziewicz, 2009; Lewicka, 2010). Czubasiewicz proved that the assessment has become an element shaping not only personal policy but it also allows to manage the organization effectively (Czubasiewicz, 2005). However, the research on the assessment systems of management staff conducted under the supervision of Listwan reveals numerous barriers arising on the way to use them effectively, e.g.: time-consuming, reluctance to be judged, bias in assessment, errors in assessment, trade union resistance, excessive shift of emphasis towards assessing and accounting professionals mainly from the point of view of the implementation of their partial tasks (Listwan and Stor, 2008). Janowska adds the lack of feedback on the results of the assessment, the preference of assessment based on the efficiency criteria and the lack of application of the results of the assessment to plan and reduce the employment or to form a salary (bonuses and rewards) to other identified dysfunctions in the assessment process (Janowska, 2010). The results of the research also reveal the fact that enterprises forfeit the systematic assessment of crew members, and there are also enterprises that do not make any assessments in general (Król, 2007).

The categorization method constitutes the basis for assessing the degree of fulfilment of functions by the ASCMS (Stabryła, 2005; Keshavarz et al., 2015). The categorization is a research process. Its essence is associated with the assessment of the condition or functioning of an object, and the qualitative qualification of an object. In contrast, the category is the qualitative class of an object, which is awarded on a fixed rating scale.

Taking into consideration the universal nature of the categorization procedure, it was used to determine the degree of fulfilment of functions by the ASCMS which are applicable in the practice of enterprises. The research conducted under the proposed categorization procedure - the ASCMS includes the following stages: defining assessment criteria, qualifying assessment criteria, performing verification assessment, preparing qualification rules. These stages of the categorization procedure are discussed below.

\section{Assessment criteria}

In the conducted research it was assumed that the ASCMS should perform three main functions: formalization, diagnostics and motivational. Therefore, the assessment of fulfilment of functions of the ASCMS will constitute the result of a kind of normative approach used in the highlighted activities of the system. In order to assess the degree of fulfilment of the function by the ASCMS, 13 criteria were included within three generic groups, which examined the level of performance of the function:

1) formalization $\left(F_{1}\right)$ :
CATEGORIZATION OF ASSESSMENT SYSTEM

Małgorzata Tyrańska 
CATEGORIZATION OF ASSESSMENT SYSTEM
Małgorzata Tyrańska

- taking into consideration the enterprise's strategy at the ASCMS design stage $\left(\mathrm{K}_{1}\right)$,

- having the rules of grading $\left(\mathrm{K}_{2}\right)$,

- systematic assessment $\left(\mathrm{K}_{3}\right)$,

- the ASCMS computerization $\left(\mathrm{K}_{4}\right)$,

- barriers to use the ASCMS $\left(\mathrm{K}_{5}\right)$,

2) diagnostic $\left(\mathrm{F}_{2}\right)$ :

- the ASCMS scope of application $\left(\mathrm{K}_{6}\right)$,

- criteria used to assess the competencies of management staff $\left(\mathrm{K}_{7}\right)$,

- usefulness of applied methods assessing competencies of management staff $\left(\mathrm{K}_{8}\right)$,

- comprehensive assessment of managerial competences on a basis of 360-degree feedback $\left(\mathrm{K}_{9}\right)$,

3) motivational $\left(\mathrm{F}_{3}\right)$ :

- usefulness of the ASCMS for personnel decisions $\left(\mathrm{K}_{10}\right)$,

- actions undertaken by the assessed management staff as a result of evaluation $\left(\mathrm{K}_{11}\right)$,

- effects of the ASCMS application in the context of enterprise management system $\left(\mathrm{K}_{12}\right)$,

- financial performance of the enterprise $\left(\mathrm{K}_{13}\right)$.

The above-mentioned criteria will be fully defined as functional assessment criteria - the ASCMS. The value of each criterion was determined by assigning them a suitably selected range of questions taken from the questionnaire used for the survey. An example of the characteristics of one of the accepted criteria together with an interpretation are presented in Table 1.

\section{Comprehensive assessment of managerial competences on a basis of 360-degree feedback}

\section{Characteristics of the criterion}

The highest level of objectivity of evaluation ensures including in the process of assessing the various actors evaluating the competencies of a given manager on a basis of 360-degree feedback. Applying the 360-degree feedback also demonstrates compliance with the principle of systematic assessment.

In the conducted research the following evaluators were distinguished:

- immediate supervisor,

- self-rated manager (self-assessment)

- subordinates,

- employees of other cells directly collaborating with the assessed manager,

- HR representative,

- representative of the Management Board,

Table 1.

- customers of the organization.

\section{Comment}

The criterion assumes a benchmark when all the above-mentioned evaluators are involved in the evaluation process. While, the lowest criterion accepts when only one evaluator assesses the competency of the manager. 
It should be added that the analysis and assessment of the degree of fulfilment of distinguished functions will also allow to respect the principles of universal importance for the construction of an effective assessment system, such as the principle of systematicity, universality, flexibility, concreteity, transparency, simplicity (Pocztowski, 2007).

\section{Qualification of assessment criteria}

After determining the evaluation criteria ASCMS, their qualification can be made. It distinguishes the following steps: (1) development of the ASCMS evaluation pattern, (2) selection of preferential aspects, (3) determination of the weight of the assessment criteria. Each of the indicated steps is briefly described below.

\section{(1) Development of the ASCMS evaluation pattern}

An evaluation pattern is a set of criteria that create an aggregate, which constitutes a multi-criteria assessment system. Evaluation patterns may be normative or postulative. Normative patterns are expressed by the magnitude (characteristics, parameters) of the data and are treated as optimal or are determined in a mandatory manner as setpoints. They are considered as extreme values, which excess or shortfall is a drawback of the system under investigation. On the other hand, the postulative patterns assume a twofold form as:

- boosters, i.e. the characteristics for which the upward trend is desired,

- dampers, i.e. the characteristics for which the downward trend is desired.

From the point of view of the degree of fulfilment of the ASCMS, pattern values are described using qualitative characteristics for each of the proposed assessment criteria. An example of a pattern for one of the accepted assessment criteria is presented in Table 2.

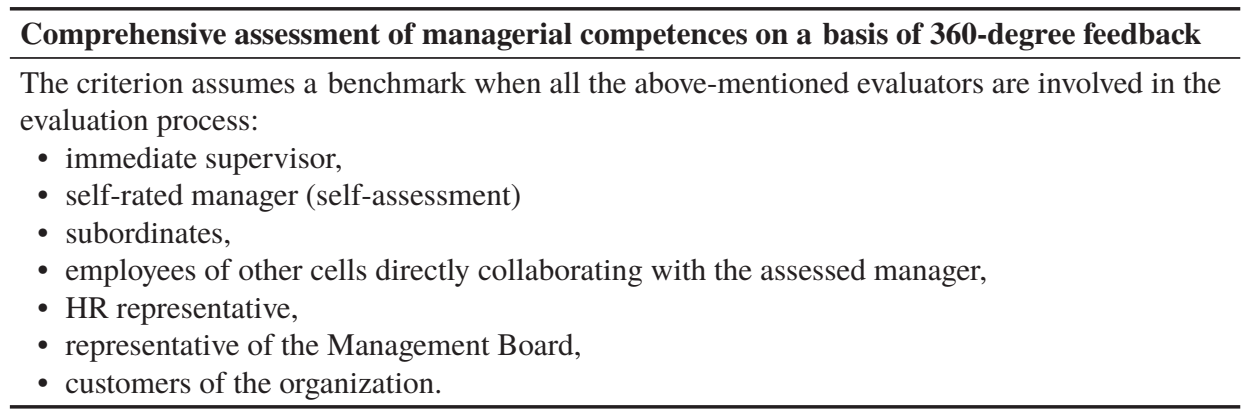

\section{(2) Selection of preferential aspects}

Preferential aspects are points of view, references, considerations that determine the importance of assessment criteria, hierarchizing them by assigning them rank or giving points. Preferential aspects are selected according to the scope

CATEGORIZATION OF ASSESSMENT SYSTEM

Małgorzata Tyrańska 
CATEGORIZATION OF ASSESSMENT SYSTEM

Małgorzata Tyrańska

Table 3.

The comparison of weights for the assessment criteria of functionality of the ASCMS

Source: own elaboration. and on the basis of content of the conducted research. As preferential aspects, any determinants of material or immaterial nature are assumed. These may be targetspecific dimensions, such as economic, organizational, technical, social, as well as situations or circumstances under which the importance of the assessment criteria is considered.

In the proposed procedure for the distinguished assessment criteria of functionality of the ASCMS, the enterprise's economic efficiency was adopted as a preferential aspect. It was considered that systematically used ASCMS leads to shaping ethical, effective and pro-efficiency behaviours of the management staff, which can be indirectly verified through financial and market results of the enterprise.

\section{(3) Determination of the weight of the assessment criteria}

Once the preferential aspects have been selected, the weights of the assessment criteria shall be determined. Weight express the importance, relevance, significance of a factor. Thus, preferential aspects serve as a benchmark according to which justification is made, why is assigned a certain weight to a given assessment criterion. In the presented research weights were determined by academic staff of the Management Process Department of Cracow University of Economics. Weights were assigned to individual criteria based on a three-point scale:

- 3 points: absolutely necessary criteria (dominant),

- 2 points: required criteria (fundamental),

- 1 point: useful criteria (good).

Table 3 presents the comparison of weights adopted by the experts for the particular assessment criteria of functionality of the ASCMS.

\begin{tabular}{llc}
\hline No. & Criterion & Weight \\
\hline $\mathrm{K}_{1}$ & Taking into consideration the enterprise's strategy at the ASCMS design stage & 3 \\
\hline $\mathrm{K}_{2}$ & Having the rules of grading & 2 \\
\hline $\mathrm{K}_{3}$ & Systematic assessment & 3 \\
\hline $\mathrm{K}_{4}$ & The ASCMS computerization & 1 \\
\hline $\mathrm{K}_{5}$ & Barriers to use the ASCMS & 2 \\
\hline $\mathrm{K}_{6}$ & The ASCMS scope of application & 2 \\
\hline $\mathrm{K}_{7}$ & Criteria used to assess the competencies of management staff & 3 \\
\hline $\mathrm{K}_{8}$ & Usefulness of applied methods assessing competencies of management staff & 2 \\
\hline $\mathrm{K}_{9}$ & Comprehensive assessment of managerial competences on a basis of 360-degree & 2 \\
\hline $\mathrm{K}_{10}$ & Useedback & 3 \\
\hline $\mathrm{K}_{11}$ & Actions undertaken by the assessed management staff as a result of evaluation & 2 \\
\hline $\mathrm{K}_{12}$ & $\begin{array}{l}\text { Effects of the ASCMS application in the context of enterprise management } \\
\text { system }\end{array}$ & 3 \\
\hline $\mathrm{K}_{13}$ & Financial performance of the enterprise & 2 \\
\hline &
\end{tabular}




\section{Performance of verification assessment}

The verification assessment indicates whether an object complies with the assumed requirements. Interpretation of the results in the verification assessment is carried out in the context of their tendency to shape, taking into account the accepted assessment criterion. Interpretation of results and their tendencies is essential for a proper verification assessment, especially in the context of multicriteria model where individual criteria are neutral variables $\left(\mathrm{K}_{1}, \mathrm{~K}_{2}, \mathrm{~K}_{3}, \mathrm{~K}_{6}, \mathrm{~K}_{7}\right.$, $\left.\mathrm{K}_{8}, \mathrm{~K}_{9}\right)$, boosters $\left(\mathrm{K}_{4}, \mathrm{~K}_{10}, \mathrm{~K}_{11}, \mathrm{~K}_{12}, \mathrm{~K}_{13}\right)$ and dampers $\left(\mathrm{K}_{5}\right)$.

The verification evaluation may be expressed in the form of an indicator or a point. The indicator form of the verification assessment corresponds to the quotient scale, while the point form to the interval scale. In the research the pattern of positive, normalized six-point verification assessment were applied (Table 4):

- 0 - unsatisfactory condition,

- 1 - acceptable condition,

- 2 - satisfactory condition,

- 3 - average condition,

- 4 - good condition,

- 5 - condition of high usefulness,

- 6 - distinctive condition.

For the purpose of the research the Author has decided to use the above assessment scale. The assessment scale has a conventional nature and includes six-point scale. Within the conducted research the point at the zero level refers to the lack of the ASCMS in the enterprise, while the points from one to six are

\begin{tabular}{lccccccc}
\hline $\begin{array}{l}\text { Assessment } \\
\text { criteria }\end{array}$ & $\mathbf{0}$ & $\mathbf{1}$ & $\mathbf{2}$ & $\mathbf{3}$ & $\mathbf{4}$ & $\mathbf{5}$ & $\mathbf{6}$ \\
\cline { 2 - 9 } $\mathrm{K}_{1}$ & 0 & & 1 & 2 & 3 & 4 & 5 \\
\hline $\mathrm{K}_{2}$ & 0 & 1 & 2 & 3 & $4-5$ & $6-7$ & $8-9$ \\
\hline $\mathrm{K}_{3}$ & 0 & 1 & & & & & 6 \\
\hline $\mathrm{K}_{4}$ & 0 & & 1 & 2 & 3 & 4 & 5 \\
\hline $\mathrm{K}_{5}$ & $8-12$ & $6-7$ & $4-5$ & 3 & 2 & 1 & 0 \\
\hline $\mathrm{K}_{6}$ & 0 & 1 & & & & & 6 \\
\hline $\mathrm{K}_{7}$ & 0 & 1 & 2 & 3 & 4 & 5 & $6-7$ \\
\hline $\mathrm{K}_{8}$ & 0 & & & 1 & 2 & 3 & 4 \\
\hline $\mathrm{K}_{9}$ & 0 & 1 & 2 & 3 & 4 & 5 & $6-7$ \\
\hline $\mathrm{K}_{10}$ & 0 & $1-2$ & $3-5$ & $6-8$ & $9-11$ & $12-14$ & $15-17$ \\
\hline $\mathrm{K}_{11}$ & 0 & & 1 & 2 & 3 & 4 & 5 \\
\hline $\mathrm{K}_{12}$ & 0 & 1 & 2 & 3 & 4 & 5 & 6 \\
\hline $\mathrm{K}_{13}$ & critical & poor & & average & & good & excellent \\
\hline
\end{tabular}


CATEGORIZATION OF ASSESSMENT SYSTEM

Małgorzata Tyrańska applied to the consecutive and higher stages of development of the ASCMS in the studied enterprises.

On the basis of tab. 4. the value of functionality index of the ASCMS ( ) is determined for each surveyed enterprise according to the formula:

$$
F_{i}=\sum_{j=1}^{n} w_{j} \cdot O_{i j}
$$

where:

$w_{j}-$ weight $j$ - of this assessment criterion,

$o_{i j}$ - point form of verification assessment referenced to the i-th enterprise,

$i=1, \ldots, m$ - enterprise,

$j=1, \ldots, n$-assessment criteria.

\section{Preparation of qualification rules}

The qualification rules are formalized representation of terms and conditions for determining the category of enterprises due to the achieved value of functionality index of the ASCMS. The qualification rules serve as a qualitative assessment tool for an investigated entity, which translates $F$-index value into a particular category. In the qualification rules are included provisions concerning: constructing the evaluation scale, setting the hierarchical ranges on the evaluation scale, marking the category of enterprises.

In the presented concept of categorization, the maximum weighted point value of $F$-index is equal to 180 . This value would have been reached by the enterprise if it had received a rating of 6 for each of the 13 distinctive assessment criteria of the ASCMS, after multiplying by weights adopted for each criterion.

The hierarchical ranges are the limits of the qualification levels that are set for $F$-index. These ranges correspond to certain categories: A, B, C, D which express importance ranking of $F$-index. The applied hierarchy of $F$-index is represented by ranges in Table 5 .
Table 5.

The adopted hierarchical ranges of the index $F_{i}$

Source: own elaboration.

\begin{tabular}{cc}
\hline Category & Score \\
\hline $\mathrm{A}$ & $145-180$ \\
\hline $\mathrm{B}$ & $108-144$ \\
\hline $\mathrm{C}$ & $72-107$ \\
\hline $\mathrm{D}$ & $0-71$ \\
\hline
\end{tabular}

The characteristics of the four categories A, B, C, D are as follows:

- category A (an enterprises with a high, very good level of functionality of the ASCMS) - size of index $F_{i}$ over $80 \%$,

- category B (an enterprises with an average, good level of functionality of the ASCMS) - size of index $F_{i}$ between $60-79 \%$, 
- category C (an enterprise with a low, satisfactory level of functionality of the ASCMS) - size of index $F_{i}$ between 40-59\%,

- category D - (an enterprises with a very low, unsatisfactory level of functionality of the ASCMS) - for index $F_{i}$ lower than $39 \%$ of its maximal value.

The stage of the category indication closes the categorization process. Within this stage, the $F$-index is calculated for each $i$-th enterprise and assigned to a specific category.

\section{The research results}

The general purpose of the empirical research was to analyze the functionality of the assessment system of competencies of management staff. The presented results are a part of the research which was performed by using the questionnaire (Tyrańska, 2015). The research was conducted between October 2011 and November 2013. The research had a regional coverage. The research covered 197 enterprises located in south-eastern Poland, operating in various industries in the Lesser Poland, Silesian and Podkarpackie voivodeships. In order to collect data, an interview method was used. It was carried out with the management staff or the managers of personal departments in the surveyed enterprises.

As a result of the $F$-index calculations, the surveyed enterprises were categorized into three successive categories indicating importance ranking of the appointed index (Figure 1).

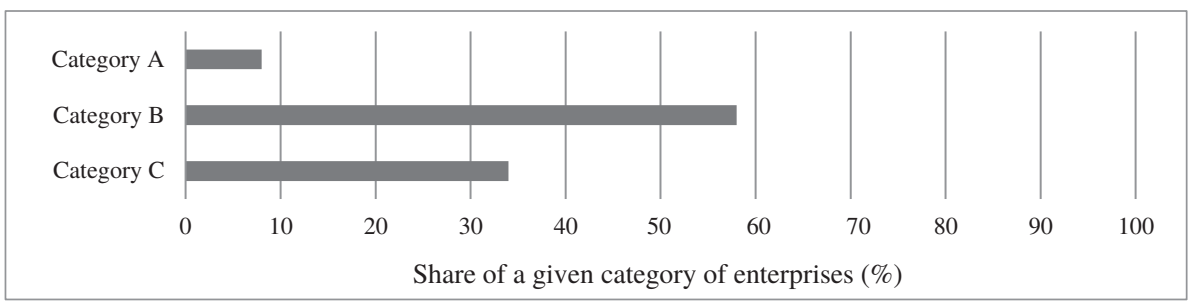

The maximum possible value of $F$-index in the method was equal to 180 points. However, none of the surveyed enterprises achieved that result. Among the enterprises analyzed, the highest value of $F$-index was 150 points. On the other hand, the lowest value of the $F$-index in the group of surveyed enterprises was 80 points.

To category A, i.e. enterprises with a high level of usefulness of the assessment systems of competencies of management staff, only $8 \%$ of the surveyed enterprises were classified. More than half of the surveyed enterprises (58\%) due to the value of the $F_{i}$ index was included in category B, i.e. enterprises with a good level of usefulness of the assessment systems of competencies of management staff. 
CATEGORIZATION OF ASSESSMENT SYSTEM

Małgorzata Tyrańska

\section{Figure 2.}

The level of implementation of the function $\mathrm{F}_{1}$ by the ASCMS in the surveyed enterprises

Source: own elaboration based on the research results.

\section{Figure 3.}

The level of implementation of the function $\mathrm{F}_{2}$ by the ASCMS in the surveyed enterprises

Source: own elaboration based on the research results.
In turn, $34 \%$ of the surveyed enterprises were classified to category $\mathrm{C}$, i.e. enterprises with a satisfactory level of usefulness of the assessment systems of competencies of management staff. Due to the obtained results of $F_{i}$ index in the surveyed enterprises, the category D, i.e. enterprises with an unsatisfactory level of usefulness of the assessment systems of competencies of management staff, was not distinguished.

The level of $F$-index is shaped by the value of three consecutive functions of the assessment systems of competencies of management staff: formalization $\mathrm{F}_{1}$, diagnostic $-\mathrm{F}_{2}$ and motivational $-\mathrm{F}_{3}$. The values of the particular functions obtained by enterprises classified in categories A, B, C are presented below.

The data analysis shows that the highest level of assessment of $F_{1}$ is in enterprises of category $A$ and amounts to a maximum of 63 points. The lowest level is in enterprises classified in category $\mathrm{C}$ and it is 37 points lower than the maximum level determined within category A (Figure 2). This condition indicates that enterprises $\mathrm{C}$ did not reach the minimum allowable level of implementation of this function.

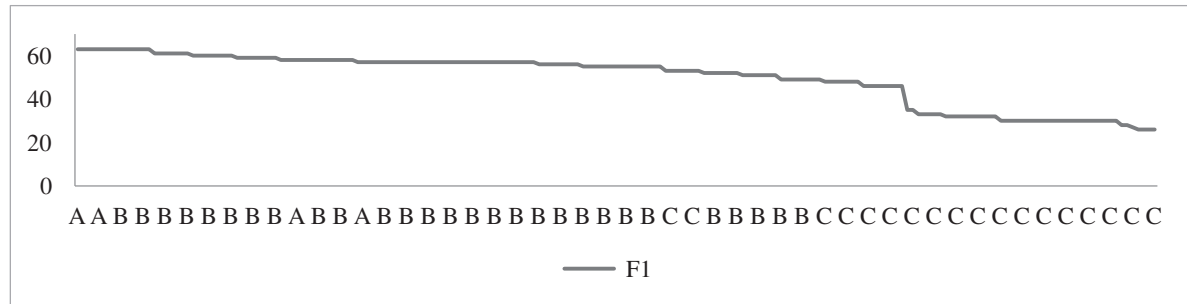

The identified maximum level of implementation of the diagnostic function is equal to 50 points and occurs in enterprises classified to category A (Figure 3). In turn, the lowest level of implementation of the function $\mathrm{F}_{2}$ accounts for 22 points and his value has been established in enterprises belonging to category $\mathrm{C}$.

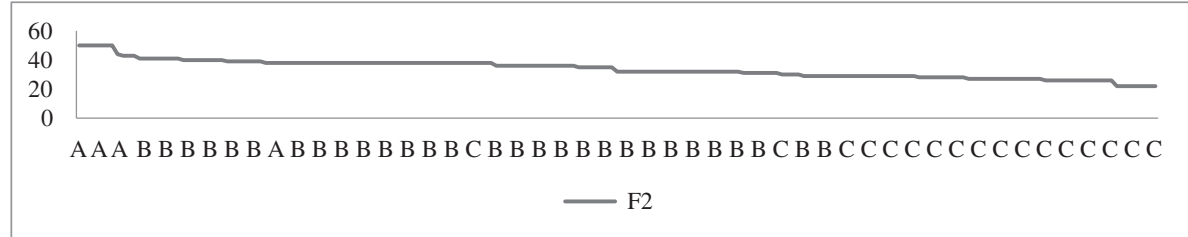

The data presented in chart 4 shows that the high level of implementation of the motivational function $-\mathrm{F}_{3}$ occurs in enterprises classified in categories $\mathrm{A}$ and $\mathrm{B}$ and is equal to 49 points. While, the lowest level of the motivational function of the ASCMS was established in enterprises of category $\mathrm{C}$ and it corresponds to 
18 points. Thus, it is less than a third of the maximum value set at the level of 60 points for the function $\mathrm{F}_{3}$.

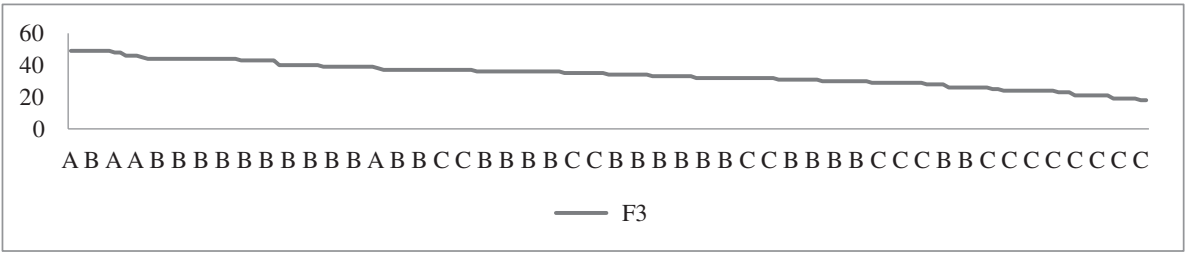

It is worrying that in none of the surveyed enterprises, even in the best enterprises in category A, good and excellent level of implementation of the motivational function within the ASCMS were not determined.

\section{Conclusions}

Summing up the results of the presented research, it should be stated that in practice of Polish enterprises the assessment systems partially allow for a holistic assessment of the competencies of management staff. The reason for the lack of full assessment of managerial competencies is the low level of functionality of the examined ASCMS. The research shows that only in enterprises classified in category A the functionality of the ASCMS ( $F$-index) is at very good level. However, enterprise of category A account for only $8 \%$ of all surveyed enterprises. In other business categories, B and C, the functionality of the ASCMS was evaluated at good and satisfactory levels.

In the surveyed enterprises, the formalization function of the ASCMS is not implemented at a perfect level. On a good level, the fulfilment of the formalization function occurred only in all enterprises of categories A and B and in 10\% of enterprises of category C. In the case of $84 \%$ of enterprises of category $C$ the level of implementation of the formalization function was assessed at a satisfactory level. The research also revealed that in the case of $6 \%$ of enterprises of category $\mathrm{C}$ the formalization function is below the allowable level.

The identified level of fulfilment of the formalization function is considered to be inadequate since in practice this function forms the basis for most of the assessment principles: transparency, simplicity, flexibility and systematicity of the assessment process of competencies of management staff. In addition, the properly implemented formalization function determines the correctness of the implementation of the remaining functions: diagnostic and motivational by the ASCMS.

The research has shown that there is a lack of regulations for assessing the competencies of management staff as well as for IT support for the implementation of a complex assessment process of managerial competencies. Failure to comply
Figure 4.

The level of implementation of the function $\mathrm{F}_{3}$ by the ASCMS in the surveyed enterprises

Source: own elaboration based on the research results. 
CATEGORIZATION OF ASSESSMENT SYSTEM

Małgorzata Tyrańska with procedural requirements results in the creation of barriers to the effective implementation of the assessment process of competencies of management staff, in particular, the correct application of diagnostic and motivational functions, resulting in destabilizing principles of personal policy.

The diagnostic function was also poorly assessed in the examined enterprises. In particular, the ideal level of this function was not established in the surveyed enterprises. The good level of the implementation of the diagnostic function was identified in $47 \%$ of enterprises of category A. For the remaining $53 \%$ of enterprises of category $\mathrm{A}$ and all enterprises belonging to categories $\mathrm{B}$ and $\mathrm{C}$, the level of diagnostic function was assessed at a satisfactory level.

The state proves that in the examined enterprises the diagnostic function of the ASCMS is not implemented properly. It leads to the lack of reliable identification of the competency gap of the evaluated managers based on updating competency profiles, which are developed for managerial positions, and assessment of actual competence level of the managers. The situation also proves that the rules are not respected in practice:

- the specificity of the evaluation process referring to the need to apply clear, measurable and work-related assessment criteria,

- flexibility assuming the adaptation of the assessment criteria and assessment methods to the specific situation and assessment goals,

- the universality of the assessment meaning that the managerial positions at all levels of management are evaluated.

The reason for this state is the lack of a comprehensive approach in assessing the competencies of management staff. In most cases, only the dynamic aspect of competencies was assessed, i.e. the effects achieved by the managers, while the assessment of the static aspect of competencies was abandoned. Basing the assessment of competencies of the management staff only on the efficiency criterion and abandoning the qualification, personality, behavioural criteria at the same time limits the accuracy of the diagnosis of managerial competencies, because it does not reveal the way of working, does not identify the attitudes and behaviours adopted by managers, limiting in such way the quality of work done by them. Therefore, it is not important how managers achieve results in the surveyed enterprises. It is important only what results are achieved.

The results showed that the methods of identifying the static aspect of assessing competencies of management staff are applied to a minimum extent, e.g. competency assessment method and complex methods, which comprehensively assess the suitability of the manager's competencies in the job (s)he occupies, e.g. assessment center, development center. Therefore, there is the lack of evaluation patterns defining the preferred competency profile of the management staff.

In addition, the research clearly indicates that the process of assessment usually involves mid- and low-level management. The competencies of managers 
who hold positions at the highest management level are rarely assessed. This situation causes that the top management is not systematically accountable for the implementation of overall tasks - strategic objectives. Due to the fact that assessment of competencies is usually concentrated in medium and low level management positions, settlements are limited to verifying partial tasks - tactical and operational objectives. Therefore, there is a lack of systematic insights into the functioning of the enterprise and rapid responses ahead of the emergence of potential crisis situations.

The lowest rating was granted to the implementation of the motivational function by the ASCMS in all surveyed enterprises. In all enterprises of categories $\mathrm{A}$ and $\mathrm{B}$, the degree of implementation of the motivational function was set at a satisfactory level. At a minimum acceptable level the motivational function is implemented in $75 \%$ enterprises qualified to category C. By contrast, in the case of $25 \%$ enterprises of category $\mathrm{C}$ the motivational function was rated as useless, which in practice means that the effects of the applied ASCMS in enterprises of category $\mathrm{C}$ are unnoticeable.

The established condition demonstrates a situation in which, on the one hand, there is limited use of the results of the assessment of competencies of the management staff in the personal decision-making process, and on the other hand, the management staff does not have the incentive to engage at the highest level of competence potential in the course of performed tasks, because it does not have to take into account the consequences of human resources decisions.

The reasons for this situation should be attributed to non-compliance with the systematicity principle within the assessment process of competencies of management staff according to which the individual elements of the ASCMS should be mutually consistent and the whole assessment system should be incorporated into the human resource management process. The results revealed that managers are not informed about the effects of competency assessment. The management staff without feedback on positive and negative aspects of the tasks performed do not modify their attitudes and behaviours towards pro-efficiency ones, which would determine the improvement of economic performance of the enterprises. Only in some of the surveyed enterprises, the results of assessment of managerial competencies are the starting point for modifying the level of bonuses, career planning, recruitment, degradation, managerial redundancy. On this basis, it can be concluded that in only few cases, the ASCMS occupies a central position in the personal policy system, which is implemented in accordance with the rules applicable to the competency management system.

\section{Notes}

[1] The publication was financed from the resources allocated to the Management Faculty of Cracow University of Economics, under the grant for the maintenance of the research potential.
CATEGORIZATION OF ASSESSMENT SYSTEM

Małgorzata Tyrańska 
CATEGORIZATION OF ASSESSMENT SYSTEM

Małgorzata Tyrańska

\section{References}

Czubasiewicz, H. (2005), Okresowe ocenianie pracowników. Konfiguracja i projektowanie systemu, Wydawnictwo Uniwersytetu Gdańskiego, Gdańsk.

Dalton, M. (1997), “Are competency models a waste?", Training \& Development Journal, Vol. 51 No. 10, pp. 46-49.

Janowska, Z. (2010), Zarzadzanie zasobami ludzkimi, Polskie Wydawnictwo Ekonomiczne, Warszawa.

Gholipur, R.A., Mahmoodi, S.M. (2012), "Presentation Model of Managerial Competency Approach in Management Development", Interdisciplinary Journal of Contemporary Research in Business, Vol. 3 No. 9, pp. 506-520.

Król, H. (2007), Zarzq̨dzanie kapitałem ludzkim a konkurencyjność małych i średnich przedsiębiorstw, Wydawnictwo Akademickie i Profesjonalne, Warszawa.

Lewicka, D. (2010), Zarządzanie Kapitałem ludzkim w polskich przedsiębiorstwach, Wydawnictwo Naukowe PWN, Warszawa.

Listwan, T., Stor, M. (2008), Zarzqdzanie kadrq menedżerskq w organizacjach międzynarodowych $w$ Polsce, Wydawnictwo Uniwersytetu Ekonomicznego we Wrocławiu, Wrocław.

Mansfield, B. (1999), "What is "competence" all about?", Competency: The Quarterly Journal, Vol. 6 No. 3, pp. 24-28.

Nesterak, J. (2010), "An appraisal of work results of employees as an element of personnel controlling", in: Borowiecki, R. (Ed.), Enterprise in the face of challenges of the $21^{\text {st }}$ century economy, Dom Organizatora, Torun, pp. 519-530.

Pocztowski, A. (2007), Zarzadzanie zasobami ludzkimi, Polskie Wydawnictwo Ekonomiczne, Warszawa.

Pocztowski, A. (2007), Funkcja personalna. Diagnoza i kierunki zmian, Wydawnictwo Uniwersytetu Ekonomicznego w Krakowie, Kraków.

Semeijn, J.H., Van Der Heijden, B.I., Van Der Lee, A. (2014), "Multisource ratings of managerial competencies and their predictive value for managerial and organizational effectiveness", Human Resource Management, Vol. 53 No. 5, pp. 773-794.

Stabryła, A. (2005), "Categorization as an Instrument in Managing Company Development Capacity”, Argumenta Oeconomica Cracoviensia, No. 3, pp. 5-29.

Tyrańska, M. (2015), Koncepcja systemu oceny kompetencji kadry menedżerskiej w przedsiębiorstwie, Wydawnictwo Uniwersytetu Ekonomicznego w Krakowie, Kraków.

Urbaniak, B., Bohdziewicz, P. (2009), Zarządzanie zasobami ludzkimi. Kreowanie nowoczesności. Raport 2009, IPiSS, Warszawa.

Witkowski, S. (1994), Psychologia sukcesu, Wydawnictwo Naukowe PWN, Warszawa. 